\title{
Pengaruh Pengetahuan Tentang Anggaran, Partisipasi Masyarakat, Transparansi Kebijakan Publik, Dan Akuntabilitas Publik Terhadap Pengawasan Keuangan Daerah Pada Dewan Perwakilan Rakyat Daerah di Wilayah Sulawesi Utara
}

\author{
AMELIA A. A. LAMBAJANG ${ }^{1}$, DAVID P. E. SAERANG ${ }^{2}$, JENNY MORASA $^{3}$ \\ ${ }^{1,2,3}$ Program Magister Akuntansi, Fakultas Ekonomi dan Bisnis Universitas Sam Ratulangi \\ email: amelialambajang@ymail.com ${ }^{1}$
}

\begin{abstract}
This study aimed to examine the effect of budget knowledge, public participation, public policy transparency, and public accountability to Regional PFinancial Control. This research was using a quantitative survey approach. Data were obtained by questionnaires filled by respondents. The respondents were chosen by a purposive sampling. Respondents are the members of the Regional House of people's Representative of Manado City and North Sulawesi Province. The data were analysed by multiple regression analysis. This results showed that: (1) budget knowledge has a positive and significant effect on regional financial control; (2) public participation has a positive and significant effect on regional financial control; (3) public policy transparency does not have a significant effect on regional financial control; (4) public accountability has a positive and significant effect on regional financial control; (5) budget knowledge, public participation, public policy transparency, and public accountability simultaneously have a positive and significant effect on regional financial control.
\end{abstract}

Keywords: Budget Knowledge. Public Participation, Public Policy Transparency, Public Accountabillity, Regional Financial Control

Abstrak. Penelitian ini bertujuan untuk menguji secara empiris pengaruh pengetahuan tentang anggaran, partisipasi masyarakat, transparansi kebijakan publik, dan akuntabilitas publik terhadap pengawasan keuangan daerah. Penelitian ini adalah penelitian kuantitatif dengan pendekatan penelitian survey. Data yang diperoleh melalui teknik survey melalui penyebaran kuisioner kepada responden penelitian. Sampel ditentukan melalui metode purposive sampling. Para responden adalah seluruh anggota DPRD Kota Manado dan anggota DPRD Provinsi Sulawesi Utara. Metode analisis data menggunakan analisis regresi linear berganda. Hasil penelitian menunjukkan bahwa: (1) pengetahuan tentang anggaran berpengaruh positif dan signifikan terhadap pengawasan keuangan daerah; (2) partisipasi masyarakat berpengaruh positif dan signifikan terhadap pengawasan keuangan daerah; (3) transparansi kebijakan publik tidak berpengaruh signifikan terhadap pengawasan keuangan daerah; (4) akuntabilitas publik berpengaruh dan signifikan terhadap pengawasan keuangan daerah; (5) variabel pengetahuan tentang anggaran, partisipasi masyarakat, transparansi kebijakan publik, dan akuntabilitas publik berpengaruh secara silmutan terhadap pengawasan keuangan daerah.

Kata Kunci : Pengetahuan Tentang Anggaran, Partisipasi Masyarakat, Transparansi Kebijakan Publik, Akuntabilitas Publik, Pengawasan Keuangan Daerah

\section{PENDAHULUAN}

Salah satu produk reformasi yang terjadi pada tahun 1998 adalah lahirnya Undang-undang Nomor 22 Tahun 1999 tentang Pemerintahan Daerah, diganti dengan Undang-undang Nomor 32 Tahun 2004, kemudian terakhir diganti lagi Undang Undang Nomor 23 Tahun 2014 yang dikenal dengan otonomi daerah. Pemberian otonomi yang seluas-seluasnya kepada daerah dilaksanakan berdasarkan prinsip negara kesatuan. Dalam negara kesatuan kedaulatan hanya ada pada pemerintahan negara atau pemerintahan nasional dan tidak ada kedaulatan pada daerah. Oleh karena itu, seluas 
apapun otonomi yang diberikan kepada daerah, tanggung jawab akhir penyelenggaraan pemerintahan daerah akan tetap ada ditangan pemerintah pusat.

Berbagai kasus yang terjadi dilingkungan dewan perwakilan rakyat daerah belakangan ini mengindikasikan bahwa kinerja dewan perwakilan rakyat daerah sebagai lembaga pengawasan politik diragukan. Salah satu penyebab utamanya adalah bahwa banyak kelompok dalam dewan perwakilan rakyat daerah sendiri belum mampu melaksanakan tata pemerintahan yang baik dan demokratis. Singkatnya, jika dewan perwakilan rakyat daerah tidak dapat menjadikan dirinya sebagai lembaga yang bersih dan berwibawa, maka fungsi pengawasan akan cenderung tidak efektif dan sekedar menjadi alat politik kepentingan. Contoh yang bisa dilihat adalah kasus korupsi yang banyak dilakukan oleh dewan perwakilan rakyat daerah. Hal ini menunjukkan jika anggota dewan perwakilan rakyat daerah tidak melaksanakan tata pemerintahan yang baik dan demokratis. Selain itu, dengan maraknya kasus korupsi dikalangan dewan perwakilan rakyat daerah membuat kepercayaan masyarakat akan berkurang.

Keuangan daerah adalah semua hak dan kewajiban daerah dalam rangka penyelenggaraan pemerintah daerah yang dapat dinilai dengan uang termasuk didalamnya segala bentuk kekayaan yang berhubungan dangan hak dan kewajiban daerah tersebut, dalam kerangka anggaran pendapatan belanja daerah (APBD) (PP No.105 Tahun 2000). Pengawasan merupakan sarana untuk menghubungkan target dengan realisasi setiap program/kegiatan/proyek yang harus dilaksanakan oleh pemerintah. Dengan kata lain, fungsi pengawasan harus dilakukan terhadap perencanaan dan pelaksanaannya. Kegiatan pengawasan sebagai fungsi manajemen bermaksud untuk mengetahui tingkat keberhasilan dan kegagalan yang terjadi setelah perencanaan dibuat dan dilaksanakan. Dalam rangka mewujudkannya, terlaksananya penyelenggaraan negara yang baik, yaitu yang transparan dan akuntabel, efektif dan efisien, serta profesional dan bertanggungjawab, juga diperlukan keterlibatan rakyat serta adanya pengetahuan tentang anggaran.

Pengetahuan yang dibutuhkan dalam melakukan pengawasan keuangan daerah salah satunya adalah pengetahuan tentang anggaran, karena dengan mengetahui anggaran maka diharapkan seluruh anggota dewan dapat mendeteksi adanya pemborosan dan kebocoran tentang anggaran. Keterlibatan rakyat tersebut sangat diperlukan untuk mengakomodasikan kepentingan mereka dalam proses penyusunan rencana pembangunan. Hal ini didasarkan pada pemikiran bahwa rakyat baik secara individu maupun kelompok adalah pihak-pihak yang berkepentingan dengan kegiatan dan hasil pembangunan, baik sebagai penanggung biaya, pelaku, penerima manfaat maupun penanggung resiko, sehingga dengan terbukanya keterlibatan masyarakat dalam pembangunan nasional tersebut maka rakyat bukan hanya sekedar pemberi amanat, tetapi juga harus terlibat aktif dalam setiap proses pembangunan nasional, termasuk dalam pengelolaan keuangan baik itu di pusat maupun dikabupaten/kota/provinsi, mulai dari tahap perencanaan sampai kepada pengawasan.

Pengawasan yang dilakukan DPRD bertujuan untuk mengembangkan kehidupan demokrasi, menjamin keterwakilan rakyat daerah dalam melaksanakan tugas dan kewenangannya serta mengembangkan mekanisme checks and balances antara DPRD dan eksekutif demi mewujudkan keadilan dan kesejahteraan rakyat (Budiardjo, 2008:318).

Pramono (2002) menyatakan yaitu bahwa pengawasan anggaran yang dilakukan oleh dewan dipengaruhi faktor internal dan eksternal. Faktor internal adalah faktor yang dimiliki oleh Anggota Dewan yang berpengaruh secara langsung terhadap fungsi dan pengawasan oleh DPRD, salah satunya adalah pengetahuan tentang anggaran. Sementara itu, faktor eksternal adalah faktor berasal dari pihak luar yang dapat memperkuat fungsi pengawasan Dewan yang tidak berpengaruh secara langsung terhadap pengawasan yang dilakukan oleh Dewan. Hal tersebut adalah adanya partisipasi masyarakat dan transparansi anggaran yang dilakukan oleh pemerintah daerah (eksekutif).

Berdasarkan uraian latar belakang sebelumnya, maka permasalahan dalam penelitian ini adalah sebagai berikut:

1. Apakah pengetahuan tentang anggaran berpengaruh positif dan signifikan terhadap pengawasan keuangan daerah?

2. Apakah partisipasi masyarakat berpengaruh positif dan signifikan terhadap pengawasan keuangan daerah?

3. Apakah transparansi kebijakan publik berpengaruh positif dan signifikan terhadap pengawasan keuangan daerah?

4. Apakah Akuntabilitas publik berpengaruh positif dan signifikan terhadap pengawasan keuangan daerah? 
Tujuan yang ingin dicapai dalam penelitian ini adalah untuk menguji secara empiris semua rumusan masalah yang ada. Bagi instansi, hasil penelitian ini diharapkan dapat memberikan informasi, sebagai bahan masukan dan pertimbangan kepada DPRD pemerintah Kota Manado maupun di tingkat DPRD Provinsi Sulawesi Utara tentang Pengaruh pengetahuan dewan tentang anggaran, partisipasi masyarakat, transparansi kebijakan publik, akuntabilitas publik terhadap pengawasan keuangan daerah. Bagi penulis, hasil penelitian ini diharapkan dapat menambah pengetahuan yang lebih mendalam mengenai ilmu akuntansi terutama SDM terkait Pengetahuan dewan tentang anggaran, partisipasi masyarakat, transparansi kebijakan publik, akuntabilitas publik, pengawasan keuangan daerah baik secara teoritis maupun praktek. Bagi akademik, hasil penelitian ini diharapkan dapat menjadi bahan referensi bagi mahasiswa, peneliti, serat kalangan akademisi lainnya yang ingin mengetahui atau memperdalam teori mengenai pengetahuan dewan tentang anggaran, partisipasi masyarakat, transparansi kebijakan publik dan akuntabilitas publik serta pengaruhnya terhadap pengawasan keuangan daerah.

\section{Gambar 1 Kerangka Konseptual Penelitian}

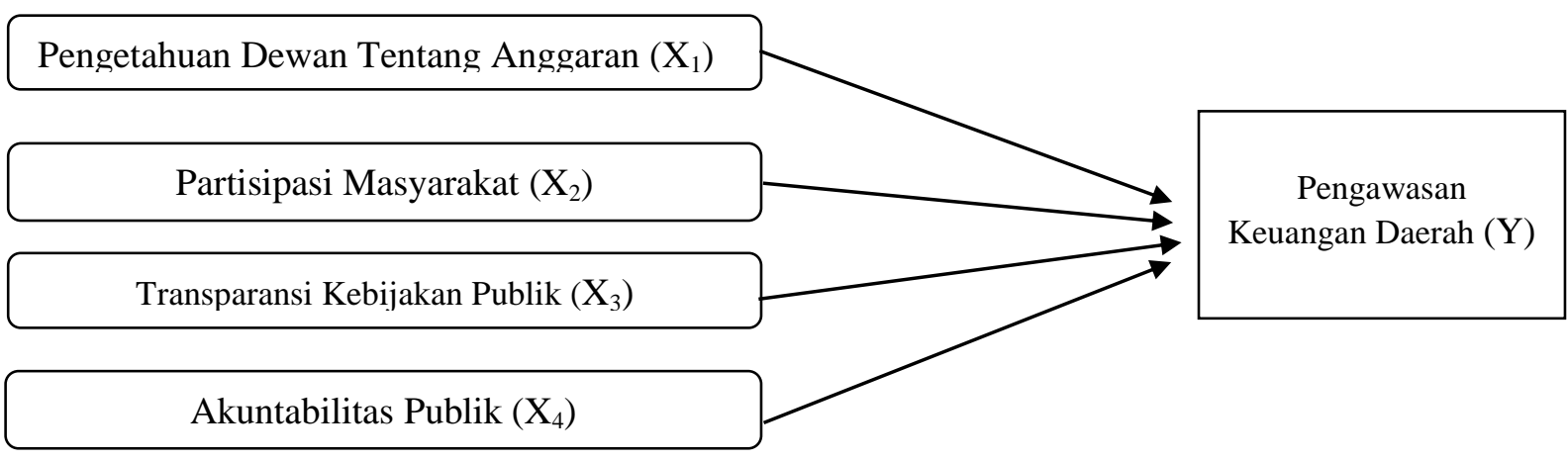

Berdasarkan landasan teori dan hasil-hasil penelitian terdahulu, maka hipotesis dalam penelitian ini dirumuskan sebagai berikut:

\section{Pengaruh Pengetahuan Tentang Anggaran Terhadap Pengawasan Keuangan Daerah}

Werimon et al (2007) mengartikan, pengetahuan sebagai kepandaian yaitu segala sesuatu yang diketahui, berkenan dengan sesuatu yang dipelajari. Pengalaman dan pengetahuan yang tinggi akan sangat membantu seseorang dalam memecahkan persoalan yang dihadapi sesuai dengan kedudukan, salah satunya sebagai anggota DPRD yang merupakan wakil rakyat. Yudono (2002) dan Coryanata (2007) menyatakan bahwa setiap anggota Dewan akan mampu menggunakan hak-haknya secara tepat, melaksanakan tugas dan kewajibannya secara efektif serta menempatkan kedudukannya secara proposional jika setiap anggota mempunyai pengetahuan yang cukup dalam hal konsepsi teknis penyelenggaraan pemerintah, kebijakan publik.

Devi (2010) menyatakan bahwa dalam organisasi sektor publik, khususnya pemerintah daerah, hubungan agensi muncul antara pemerintah daerah sebagai agen dan DPRD sebagai Prinsipal dan publik/warga berlaku sebagai prinsipal yang memberikan otoritas kepada DPRD (agen) untuk mengawasi kinerja pemerintah daerah. Hasil penelitian Werimon (2005) menunjukkan bahwa pertama, terdapat hubungan yang positif signifikan antara variabel pengetahuan anggota DPRD tentang anggaran dengan pengawasan keuangan daerah. Penelitian yang dilakukan Sopanah (2003) dan Roseptalia (2006) hasilnya bahwa pengetahuan dewan tentang anggaran berpengaruh signifikan terhadap pengawasan keuangan daerah. Dan interaksi antara pengetahuan dewan tentang anggaran dengan partisipasi masyarakat berpengaruh signifikan terhadap pengawasan keuangan daerah. Berdasarkan penjelasan tersebut, maka dalam penelitian ini hipotesis1 yang diajukan yakni sebagai berikut:

$\mathrm{H}_{1}$ : Pengetahuan dewan tentang anggaran berpengaruh positif dan signifikan terhadap pengawasan keuangan daerah. 


\section{Pengaruh Partisipasi Masyarakat Terhadap Pengawasan Keuangan Daerah}

Syaiful (2009) menegaskan, bahwa partisipasi masyarakat kunci sukses dalam pelaksanaan otonomi daerah karena dalam partisipasi yaitu menyangkut tentang aspek pengawasan dan aspirasi. Menyadari pentingnya aspirasi masyarakat, maka diperlukan langkah strategis agar partisipasi masyarakat bisa berjalan secara kondusif. Salah satu upaya yang bisa dilakukan adalah mengoptimalkan peran dari lembaga institusi lokal non pemerintahan seperti Lembaga Swadaya Masyarakat (LSM), media masa, organisasi kemasyarakatan dan partai politik. Pengetahuan tentang anggaran yang mempengaruhi pengawasan yang dilakukan oleh dewan, partisipasi masyarakat diharapkan akan meningkatkan fungsi pengawasan (Nasirwan, 2008). Selain pengetahuan anggota dewan, faktor yang berpengaruh positif signifikan terhadap pengawasan APBD adalah partisipasi masyarakat. Adanya keterlibatan masyarakat akan memperkuat proses penyelenggaraan pemerintah, maka peranan dewan dalam melakukan pengawasan keuangan daerah akan dipengaruhi oleh keterlibatan masyarakat dalam proses penganggaran. Penelitian yang dilakukan oleh Saputro (2012) menyatakan bahwa partisipasi masyarakat dan transparansi kebijakan publik terhadap pengawasan berpengaruh signifikan yang positif.

Partisipasi masyarakat dalam penganggaran harus dilakukan pada setiap tahapan dalam siklus anggaran mulai dari penyusunan, ratifikasi, pelaksanaan, sampai dengan pertanggungjawaban dalam penelitian Mardiasmo (2002: 70). Penelitian Sopanah dan Wahyudi (2009) yang menyatakan bahwa partisipasi masyarakat berpengaruh signifikan terhadap hubungan antara pengetahuan anggaran dengan pengawasan keuangan daerah. Berdasarakan penjelasan tersebut, maka dalam penelitian ini hipotesis 2 yang diajukan yakni sebagai berikut:

\section{$\mathrm{H}_{2}$ : Partisipasi masyarakat berpengaruh positif dan signifikan terhadap pengawasan keuangan daerah.}

\section{Pengaruh Transparansi Kebijakan Publik terhadap Pengawasan Keuangan Daerah}

Mardiasmo (2002) transparansi merupakan keterbukaan (openness) pemerintah dalam memberikan informasi yang terkait dengan aktivitas pengelolahan sumber daya publik kepada pihakpihak yang membutuhkan informasi. Transparansi merupakan salah satu prinsip dari good governance. Transparansi dibangun atas dasar arus informasi yang bebas, seluruh proses pemerintahan, lembagalembaga dan informasi perlu dapat diakses oleh pihak-pihak yang berkepentingan, dan informasi yang tersedia harus memadai agar dapat dimengerti dan dipantau. Transparansi juga bisa berarti informasi yang cukup berkaitan dengan kinerja lembaga tersedia dan disajikan dalam bentuk atau media yang mudah dipahami masyarakat (Amin, 2008). Transparansi Kebijakan Publik adalah keterbukaan tentang anggaran yang mudah diakses oleh masyarakat. Kebijakan publik merupakan tindakan yang dilakukan oleh pemerintah dan sebagai keputusan yang mempunyai tujuan tertentu (Pangesti, 2013).

Hasil dari penelitian ini mendukung penelitian Sopanah dan Wahyudi (2009) menyatakan bahwa transparansi kebijakan publik berpengaruh signifikan terhadap hubungan antara pengetahuan anggaran dengan pengawasan keuangan daerah. Penelitian yang dilakukan oleh Saputro (2012) menyatakan bahwa partisipasi masyarakat dan transparansi kebijakan publik terhadap pengawasan berpengaruh signifikan yang positif. Sesuai dengan uraian tersebut maka hipotesis 3 yang diajukan pada penelitian ini adalah sebagai berikut:

$\mathrm{H}_{3}$ : Transparansi kebijakan publik berpengaruh positif dan signifikan terhadap pengawasan keuanagan daerah.

\section{Pengaruh Akuntabilitas Publik Terhadap Pengawasan Keuangan Daerah}

Sulistoni (2003) menyatakan bahwa pemerintah yang accountable memiliki ciri-ciri sebagai berikut (1) mampu menyajikan informasi penyelenggaraan pemerintah secara terbuka, cepat dan tepat kepada masyarakat, (2) mampu memberikan pelayanan yang memuaskan bagi publik, (3) mampu memberikan ruang bagi masyarakat untuk terlibat dalam proses pembangunan dan pemerintahan, (4) mampu menjelaskan dan mempertanggungjawabkan setiap kebijakan publik secara proposional, dan (5) adanya sarana bagi publik untuk menilai kinerja pemerintah.

Akuntabilitas publik akan tercapai jika pengawasan yang dilakukan oleh dewan dan masyarakat berjalan secara efektif. Hal ini juga di dukung oleh pendapatnya Rubin (1996) yang menyatakan bahwa untuk menciptakan akuntabilitas kepada publik diperlukan partisipasi pimpinan instansi dan warga masyarakat dalam penyusunan dan pengawasan keuangan daerah (APBD). Sehingga akuntabilitas publik yang tinggi akan memperkuat fungsi pengawasan yang dilakukan oleh dewan. 
Penelitian yang dilakukan oleh I Gede Sudiarta (2014) menyatakan bahwa akuntabilitas publik berpengaruh positif signifikan terhadap hubungan antara pengetahuan dewan tentang anggaran dengan pengawasan keuangan daerah APBD. Penelitian yang dilakukan oleh Novatianti (2010) menyatakan bahwa akuntabilitas publik, partisipasi masyarakat dan transparansi kebijakan publik berpengaruh yang signifikan terhadap pengawasan keuangan daerah. Hasil penelitian yang dilakukan oleh Setyawan (2016) menunjukan bahwa pengaruh positif akuntabilitas publik, transparansi kebijakan publik dan pengawasan terhadap pengelolaan keuangan daerah sesuai dengan prinsip. Berdasarkan penjelasan tersebut, maka dalam penelitian ini hipotesis 4 yang diajukan yakni sebagai berikut.

$\mathrm{H}_{4}$ : Akuntabilitas publik berpengaruh positif dan signifikan terhadap pengawasan keuangan daerah

\section{Metode Penelitian}

Jenis penelitian ini adalah jenis penelitian kuantitatif. Sumber data yang digunakan dalam penelitian ini yaitu data primer yang diperoleh dengan menggunakan instrumen daftar pertanyaan (kuesioner). Populasi dalam penelitian ini adalah semua anggota Dewan Perwakilan Rakyat Daerah (DPRD) yang berada di Kabupaten Sitaro. Dikarenakan populasi penelitian tidak terlalu besar, maka peneliti tidak menggunakan teknik pengambilan sampel.

\section{Definisi Operasional dan Pengukuran Variabel Variabel Dependen}

Pengawasan keuangan daerah dapat diartikan sebagai segala bentuk tindakan untuk menjamin pengelolaan keuangan daerah berjalan sesuai dengan tujuan, rencana, dan aturan-aturan secara efektif, efisien dan ekonomis. Variabel ini diukur dengan skala likert 1-5.

\section{Variabel Independen}

1. Pengetahuan Tentang Anggaran

Pengetahuan yang dimiliki oleh tiap-tiap anggota dewan baik itu pengalaman secara pribadi/dasar maupun pengetahuan dalam hal berpikir dan bertindak, serta melakukan pemecahan masalah dalam tugas yang dipercayakan sebagai anggota DPRD dan mampu menggunakan hak-hak secara proposional, sebagai pihak ketiga yang menjembatani kepentingan rakyat, juga mengetahui suatu konsepsi atau suatu teknis untuk menyusun anggaran serta kebijakan-kebijakan publik untuk mengawasi juga kinerja dari pemerintah daerah agar selalu efektif dan efisien dalam pelaksanaan anggaran agar tidak mengalami kegagalan. Variabel ini diukur dengan skala likert 1-5.

\section{Partisipasi masyarakat}

Partisipasi berarti memberikan hak kepada masyarakat untuk memberi masukan dalam pembentukan prolegda, secara bersamaan mewajibkan Pemda dan DPRD mempermudah masukan/aspirasi tersebut sampai pada mereka. Variabel ini diukur dengan skala likert 1-5.

\section{Transparansi kebijakan publik}

Suatu anggaran yang disusun dari pihak eksekutif dan memiliki kriteria juga yaitu: harus terdapat kebijakan anggaran, tersedianya dokumen anggaran dan mudah di akses, tersedia laporan pertanggungjawaban yang tepat waktu, terakomodasinya suara/usulan rakyat, terdapat sistem pemberian informasi kepada publik. Variabel ini diukur dengan skala likert 1-5.

\section{Akuntabilitas Publik}

Akuntabilitas publik yang memiliki ciri-ciri mampu menyajikan informasi penyelenggara pemerintah secara terbuka, cepat tepat kepada masyarakat, mampu juga memberikan pelayanan yang memuaskan bagi publik, memberikan ruang bagi masyarakat untuk terlibat dalam suatu proses pembangunan dan program-program dari pemerintah, serta mampu menjelaskan dan mempertanggung jawabkan setiap kebijakan publik secara proposional dan dengan adanya sarana bagi publik masyarakat juga dapat menilai secara langsung kinerja dari pemerintah. Variabel ini diukur dengan skala likert 1-5. 


\section{Hasil dan Pembahasan}

Penelitian ini mengambil objek Dewan Perwakilan Rakyat Daerah (DPRD) Wilayah Sulawesi Utara, yang terdiri dari DPRD Provinsi Sulawesi Utara dan DPRD Kota Manado. Sebanyak 85 buah kuesioner disebarkan kepada seluruh Anggota DPRD, yang terdiri dari 45 kuesioner untuk anggota DPRD Provinsi Sulawesi Utara dan 40 Kuesioner untuk DPRD anggota DPRD Kota Manado. Dari jumlah kuesioner yang disebarkan tersebut, terdapat 78 buah kuesioner yang dikembalikan. Sehingga kuesioner yang layak digunakan adalah sebanyak 78 buah yakni dengan persentase $91,76 \%$.

\section{Uji Validitas dan Reliabilitas}

Uji validitas bertujuan untuk mengukur valid atau tidaknya suatu item pertanyaan, sedangkan uji reliabilitas bertujuan untuk mengukur konsisten atau tidaknya jawaban dari seseorang terhadap setiap item pertanyaan yang terdapat dalam sebuah kuesioner. Hasil uji validitas untuk variabel pengetahuan tentang anggaran, partisipasi masyarakat, dan Akuntabilitas publik valid sedangkan variabel transparansi kebijakan publik tidak valid dimana nilai $r$ tabel sebesar 0,227 . Untuk uji reliabilitas diperoleh nilai Cronbach's Alpha untuk variabel Pengetahuan tentang Anggaran sebesar 0,609; Partisipasi Masyarakat sebesar 0,702; Transparansi Kebijakan Publik sebesar 0,642; Akuntabilitas Publik sebesar 0.610; dan Pengawasan Keuangan Daerah sebesar 0,624. Dengan demikian dapat disimpulkan bahwa pertanyaan dalam kuesioner ini reliable karena memiliki nilai Cronbach's Alpha > 0,60. Pertanyaan dalam kuesioner ini reliable karena memiliki nilai Cronbach's Alpha > 0,60.

\section{Uji Asumsi Klasik}

\section{Uji Normalitas}

Uji normalitas bertujuan untuk menguji apakah dalam model regresi, variabel terikat dengan variabel bebas keduanya mempunyai distribusi normal atau tidak. Untuk mengetahui data berdistribusi secara normal dilakukan uji Normality P-Plot.

\section{Gambar 2 \\ Output Pengujian Normalitas P-Plot}

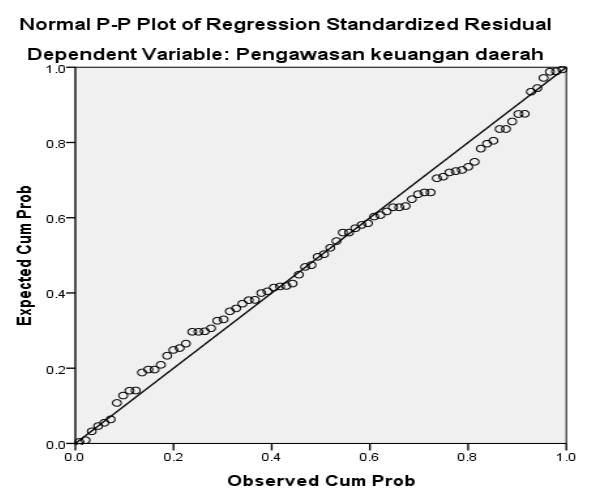

Berdasarkan Gambar 2 di atas dapat dilihat grafik Normal P-P Plot of regression standardized residual menggambarkan penyebaran data tersebar disekitar garis diagonal dan penyebarannya mengikuti arah garis diagonal grafik tersebut. Untuk itu model regresi yang digunakan dalam penelitian ini telah memenuhi asumsi normalitas.

Tabel 1

Hasil Uji Normasiltas Kolmogorov-Smirnov Tests of Normality

\begin{tabular}{|c|c|c|c|c|c|c|}
\hline & \multicolumn{3}{|c|}{ Kolmogorov-Smirnov ${ }^{\mathrm{a}}$} & \multicolumn{3}{|c|}{ Shapiro-Wilk } \\
\hline & Statistic & df & Sig. & Statistic & Df & Sig. \\
\hline Unstandardized Residual & .067 & 78 & $.200^{\circ}$ & .983 & 78 & .407 \\
\hline
\end{tabular}

Berdasarkan Tabel 1. Dapat dilihat hasil uji Kolmogorov-Smirnov menunjukkan Sig. sebesar $0,200>0,05$. Artinya nilai residual menyebar secara normal, maka model regresi yang digunakan dalam penelitian ini telah memenuhi asumsi normalitas. 


\section{Uji Multikolinearitas}

Uji Multikolinearitas digunakan untuk mengetahui apakah terjadi korelasi yang kuat di antara variabel-variabel independen yang diikutsertakan dalam pembentukan model. Hasil coefficients pada output coefficients model, dikatakan tidak terjadi gejala multikolinearitas jika mempunyai nilai tolerance di atas 0,1 atau $\mathrm{VIF}<10$.

Tabel 2

Hasil Uji Multikolinearitas

\begin{tabular}{|ll|r|r|}
\hline \multirow{2}{*}{ Model } & \multicolumn{2}{|c|}{ Collinearity Statistics } \\
\cline { 2 - 3 } & Tolerance & \multicolumn{1}{|c|}{ VIF } \\
\hline $1 \quad$ (Constant) & & \\
& Pengetahuan tentang anggaran $\left(\mathrm{X}_{1}\right)$ & .894 & 1.119 \\
Partisipasi masyarakat $\left(\mathrm{X}_{2}\right)$ & .917 & 1.091 \\
Transparansi kebijakan publik $\left(\mathrm{X}_{3}\right)$ & .907 & 1.102 \\
Akuntabilitas publik $\left(\mathrm{X}_{4}\right)$ & .868 & 1.153 \\
\hline
\end{tabular}

Berdasarkan hasil coefficients yang terdapat pada Tabel 5.17 diketahui bahwa nilai tolerance dari masing-masing variabel independen di atas 0,1 dan nilai VIF dari masing-masing variabel independen lebih kecil dari pada 10, yaitu nilai VIF untuk variabel pengetahuan tentang anggaran $\left(\mathrm{X}_{1}\right)$ adalah sebesar $1.119<10$ dan nilai tolerance $0,894>0,10$; nilai VIF untuk partisipasi masyarakat $\left(\mathrm{X}_{2}\right)$ adalah sebesar $1.091<10$ dan nilai tolerance $0,917>0,10$; nilai VIF untuk variabel transparansi kebijakan publik $\left(\mathrm{X}_{3}\right)$ adalah sebesar $1.102<10$ dan nilai tolerance $0,907>0,10$; nilai VIF untuk variabel akuntabilitas publik $\left(\mathrm{X}_{4}\right)$ adalah sebesar $1.153<10$ dan nilai tolerance $0,868>0,10$. Dengan demikian dapat disimpulkan bahwa tidak terjadi gejala multikolinearitas antara variabel komitmen organisasi, pengendalian intern akuntansi, peran internal audit, pendidikan, dan kualitas pelatihan dalam model penelitian ini.

\section{Uji Heteroskedastisitas}

Untuk uji heteroskedastisitas menggunakan uji Glesjer. Jika probabilitas signifikansi masing-masing variabel independen $>0,05$, maka dapat disimpulkan tidak terjadi heteroskedastisitas dalam model regresi (Ghozali, 2016).

Tabel 3

Coefficients $^{\mathrm{a}}$

\begin{tabular}{|c|c|c|c|c|c|c|}
\hline \multirow{2}{*}{\multicolumn{2}{|c|}{ Model }} & \multicolumn{2}{|c|}{$\begin{array}{c}\text { Unstandardized } \\
\text { Coefficients }\end{array}$} & \multirow{2}{*}{$\begin{array}{c}\text { Standardized } \\
\text { Coefficients }\end{array}$} & \multirow[b]{2}{*}{$\mathrm{t}$} & \multirow[b]{2}{*}{ Sig. } \\
\hline & & $\mathrm{B}$ & Std. Error & & & \\
\hline \multirow[t]{5}{*}{1} & (Constant) & 5.372 & 1.856 & & 2.894 & .005 \\
\hline & Pengetahuan tentang anggaran $\left(X_{1}\right)$ & -.102 & .056 & -.215 & -1.832 & .071 \\
\hline & Partisipasi masyarakat $\left(\mathrm{X}_{2}\right)$ & .019 & .055 & .039 & .340 & .735 \\
\hline & Transparansi kebijakan publik $\left(\mathrm{X}_{3}\right)$ & -.026 & .044 & -.069 & -.593 & .555 \\
\hline & Akuntabilitas publik $\left(\mathrm{X}_{4}\right)$ & -.088 & .060 & -.176 & -1.480 & .143 \\
\hline
\end{tabular}

Uji heteroskedastisitas menghasilkan nilai signifikansi masing-masing variabel lebih besar dari 0,05 yang berarti bahwa secara statistik berarti variabel tidak berpengaruh secara signifikan statistik karena p-value lebih besar dari 0,05 .

\section{Uji Hipotesis Penelitian}

\section{Pengujian Hipotesis Dengan Uji t}

Penggunaan regresi linier berganda memberikan hasil seperti yang disajikan pada tabel 4 sehingga dapat diketahui koefisien untuk persamaan regresi dari data yang diteliti. 
Tabel 4

Koefisien Regresi

\begin{tabular}{|ll|r|r|}
\hline \multirow{2}{*}{ Model } & \multicolumn{2}{|c|}{ Unstandardized Coefficients } \\
\cline { 3 - 4 } & B & \multicolumn{2}{|c|}{ Std. Error } \\
\hline 1 & (Constant) & 4.536 & 3.002 \\
& Pengetahuan tentang anggaran & .180 & .090 \\
& Partisipasi masyarakat & .305 & .088 \\
& Transparansi kebijakan publik & .108 & .071 \\
& Akuntabilitas publik & .233 & .097 \\
\cline { 2 - 4 } & & &
\end{tabular}

Hasil tersebut bila dimasukkan ke dalam persamaan penelitian menjadi:

$Y=4,536+0,180 X_{1}+0,305 X_{2}+0,108 X_{3}+0,233 X_{4}+m$

\section{Uji Statistik F}

Uji F ini dilakukan untuk mengetahui apakah variabel independen yaitu pengetahuan tentang angaran $\left(\mathrm{X}_{1}\right)$, partisipasi masyarakat $\left(\mathrm{X}_{2}\right)$, transparansi kebijakan publik $\left(\mathrm{X}_{3}\right)$, dan akuntabilitas publik $\left(\mathrm{X}_{4}\right)$ secara bersama-sama berpengaruh terhadap variabel dependen yaitu pengawasan keuangan daerah(Y).

Tabel 5

\section{Hasil Uji F}

ANOVA $^{\mathrm{a}}$

\begin{tabular}{|c|c|c|c|c|c|c|}
\hline & & $\begin{array}{c}\text { Sum of } \\
\text { Squares }\end{array}$ & df & $\begin{array}{l}\text { Mean } \\
\text { Square }\end{array}$ & $\mathrm{F}$ & Sig. \\
\hline \multirow{2}{*}{$\frac{\mathrm{M}}{1}$} & Regression & 83.448 & 4 & \multirow{3}{*}{$\begin{array}{r}20.862 \\
2.279\end{array}$} & \multirow[t]{3}{*}{9.152} & \multirow[t]{3}{*}{$.000^{\mathrm{b}}$} \\
\hline & Residual & 166.398 & 73 & & & \\
\hline & Total & 249.846 & 77 & & & \\
\hline
\end{tabular}

Berdasarkan Tabel 5 nilai $\mathrm{F}_{\text {hitung }}=9,152$, angka ini lebih besar dari nilai $\mathrm{F}_{\text {tabel }}=2,50$ pada tingkat $p$ value pada kolom signifikan adalah 0,000 angka ini lebih kecil dari 0,05. Dengan demikian maka dapat disimpulkan bahwa $\mathrm{H}_{o}$ ditolak dan $\mathrm{H}_{\mathrm{a}}$ diterima. Hal ini berarti, pengetahuan tentang anggaran $\left(\mathrm{X}_{1}\right)$, pengendalian partisipasi masyarakat $\left(\mathrm{X}_{2}\right)$, transparansi kebijakan publik $\left(\mathrm{X}_{3}\right)$, akuntabilitas publik $\left(\mathrm{X}_{4}\right)$ secara bersama-sama berpengaruh positif dan signifikan terhadap variabel dependen yaitu pengawasan keuangan daerah(Y).

\section{Koefisien Determinasi $\left(\mathbf{R}^{2}\right)$ dan Korelasi $(\mathbf{r})$}

Analisis koefisien korelasi digunakan untuk mengukur besarnya pengaruh hubungan antara variabel independen (X) terhadap variabel dependen (Y). Pada penelitian ini mengukur kuat lemahnya hubungan antara Pengetahuan Tentang Anggaran $\left(\mathrm{X}_{1}\right)$, Partisipasi Masyarakat $\left(\mathrm{X}_{2}\right)$, Transparansi Kebijakan Publik $\left(\mathrm{X}_{3}\right)$, dan Akuntabilitas Publik $\left(\mathrm{X}_{4}\right)$ terhadap Pengawasan Keuangan Daerah (Y).

Tabel 6

Hasil Koefisien Determinasi $\left(\mathbf{R}^{2}\right)$ dan Korelasi (r) Model Summary

\begin{tabular}{|l|r|r|r|c|}
\hline Model & R & R Square & Adjusted R Square & $\begin{array}{c}\text { Std. Error of the } \\
\text { Estimate }\end{array}$ \\
\hline 1 & $.578^{\mathrm{a}}$ & .334 & .298 & 1.5098 \\
\hline
\end{tabular}

Berdasarkan hasil tabel 6 di atas dapat dilihat nilai adjusted $\mathrm{R}^{2}$ adalah sebesar 0,298 atau 29,80\%. Angka tersebut berarti sebesar 29,80\% pengawasan keuangan daerah pada Dewan Perwakilan Rakyat Daerah di Sulawesi Utara dapat dijelaskan oleh variabel Pengetahuan Tentang Anggaran $\left(\mathrm{X}_{1}\right)$, Partisipasi Masyarakat $\left(\mathrm{X}_{2}\right)$, Transparansi Kebijakan Publik $\left(\mathrm{X}_{3}\right)$, dan Akuntabilitas Publik $\left(\mathrm{X}_{4}\right)$. Sedangkan sisanya $(100 \%-29,80 \%=70,20 \%)$ disebabkan oleh faktor-faktor lain diluar pengujian ini. 
Berdasarkan pada Tabel 6 koefisien korelasi (R) sebasar 0,578 menunjukkan bahwa hubungan (korelasi) antara variabel independen dengan variabel dependen merupakan hubungan yang kuat. Artinya Pengetahuan dewan tentang anggaran $\left(X_{1}\right)$, Partisipasi masyarakat $\left(X_{2}\right)$, Transparansi kebijakan publik $\left(\mathrm{X}_{3}\right)$, dan Akuntabilitas publik $\left(\mathrm{X}_{4}\right)$ terhadap pengawasan keuangan daerah mempunyai hubungan yang kuat.

\section{Pembahasan}

\section{Pengaruh Pengetahuan Tentang Anggaran Terhadap Pengawasan Keuangan Daerah.}

Hasil pengujian menunjukkan bahwa variabel pengetahuan tentang anggaran berpengaruh positif dan signifikan secara statistik terhadap pengawasan keuangan daerah. Dengan demikian hipotesis 1 terdukung karena secara empirik terbukti. Interpretasi dari temuan penelitian ini menunjukkan bahwa terdapat hubungan antara pengetahuan tentang anggaran dan pengawasan keuangan daerah pada Dewan Perwakilan Rakyat Daerah di Sulawesi Utara. Hal ini menunjukkan bahwa Pengawasan keuangan daerah didukung oleh pengetahuan tentang anggaran. Artinya pengetahuan tentang anggaran yang baik mampu menunjang peningkatan pengawasan keuangan daerah. Semakin baik Pengetahuan tentang anggaran, maka semakin baik pula pengawasan keuangan daerah.

Temuan ini sesuai dengan penelitian sebelumnya yang dilakukan oleh Utama (2015) menyatakan bahwa Pengetahuan Dewan tentang anggaran berpengaruh positif signifikan terhadap Pengawasan Keuangan Daerah. Hasil penelitiannya menunjukkan bahwa dengan adanya Pengaruh Pengetahuan Dewan Tentang Anggaran akan mempertahankan proses pengawasan keuangan daerah sehingga dapat meningkatkan bentuk pengawasan keuangan daerah yang dilakukan oleh anggota dewan. Temuan ini juga sesuai dengan penelitian sebelumnya yang dilakukan oleh Rustiyaningsih (2013) menyatakan bahwa pengetahuan dewan tentang anggaran berpengaruh terhadap kualitas pengawasan keuangan daerah. Hasil penelitiannya menunjukkan bahwa semakin tinggi pengetahuan tentang anggaran yang dimiliki oleh anggota dewan semakin baik pula kualitas terhadap pengawasan keuangan daerah yang dihasilkan. Pengetahuan dan kemampuan yang dimiliki oleh anggota dewan dalam melaksanakan pengawasan yang berkaitan dengan pengawasan keuangan daerah, akan semakin baik kesejahteraan kepada masyarakat.

Temuan ini sejalan dengan teori yang dikemukakan oleh Ritzer (1992:57) menyatakan bahwa individu melakukan suatu tindakan berdasarkan pengalaman, persepsi, pemahaman, dan penafsirannya atas suatu obyek stimulus atau situasi tertentu. Tingginya Pengetahuan tentang anggaran akan meningkatkan pengawasan keuangan daerah DPRD Provinsi dan Kota. Artinya semakin banyak kemampuan dewan dalam hal menyusun anggaran maka semakin baik pula pengawasan keuangan daerah.

\section{Pengaruh Partisipasi Masyarakat Terhadap Pengawasan Keuangan Daerah}

Hasil pengujian menunjukkan bahwa variabel partisipasi masyarakat terhadap pengawasan keuangan daerah pada DPRD Provinsi dan kota. Dengan demikian hipotesis 2 terdukung karena secara empirik terbukti. Interpretasi dari temuan penelitian ini menunjukkan bahwa terdapat hubungan antara partisipasi masyarakat terhadap pengawasan keuangan daerah DPRD Provinsi dan Kota. Hal ini menunjukkan bahwa pengawasan keuangan daerah didukung oleh partisipasi masyarakat. Artinya partisipasi masyarakat yang memadai mampu menunjang peningkatan pengawasan keuangan daerah. Semakin baik partisipasi masyarakat, maka semakin baik pula pengawasan keuangan daerah. Partisipasi masyarakat akan memberikan suatu aspirasi atau membantu dalam hal pengawasan maka akan baik pula kinerja anggota dewan dalam melakukan suatu pengawasan keuangan daerah.

Temuan ini didukung dengan hasil penelitian sebelumnya yang dikemukakan oleh Ghozali (2015). Pengaruh partisipasi masyarakat dan transparansi kebijakan publik terhadap hubungan diantara pengetahuan dewan tentang anggaran dengan pengawasan keuangan daerah (APBD). Hasil Penelitian: 1) Hasil analisis regresi terhadap hipotesis pertama dapat dilihat bahwa pengetahuan Dewan tentang anggaran berpengaruh positif signifikan terhadap pengawasan keuangan daerah (APBD). 2) Hasil analisis regresi terhadap hipotesis ke dua dapat dilihat bahwa interaksi antara pengetahuan dewan tentang anggaran dengan partisipasi masyarakat berpengaruh negatif signifikan terhadap pengawasan APBD. 3) Berdasarkan hasil uji hipotesis ke tiga dapat dilihat bahwa interaksi antara pengetahuan dewan tentang anggaran dengan transparansi kebijakan publik tidak berpengaruh positif signifikan terhadap pengawasan APBD. Uji hipotesis ke empat dapat dilihat bahwa interaksi antara pengetahuan dewan tentang anggaran dengan partisipasi masyarakat dan transparansi kebijakan 
publik tidak berpengaruh positif signifikan terhadap pengawasan APBD. Temuan yang dilakukan oleh Saputro (2012) pengaruh partisipasi masyarakat dan transparansi kebijakan publik terhadap hubungan antara pengetahuan dewan tentang anggaran dengan pengawasan keuangan daerah. Hasil penelitiannya Interaksi partisipasi masyasrakat dan kebijakan publik terhadap pengawasan berpengaruh signifikan yang positif juga pengetahuan tentang anggaran terhadap pengawasan keuangan daerah.

Hal ini mengkonfirmasi asumsi filosofi dari Stakeholder theory merupakan sekelompok orang, komunitas atau masyarakat baik secara keseluruhan maupun parsial yang memiliki 10 hubungan serta kepentingan terhadap organisasi (Putro, 2013). Dalam penelitian ini teori stakeholder menjelaskan tentang pentingnya peranan masyarakat selaku stakeholder untuk dapat berpartisipasi dalam pengembangan kebijakan publik terhadap pengawasan keuangan daerah. Tingginya Partisipasi masyarakat maka akan meningkatkan pengawasan keuangan daerah DPRD Provinsi dan Kota. Artinya partisipasi masyarakat sangat berpengaruh terhadap pengawasan keuangan daerah yang dilakukan oleh dewan, baik di Provinsi maupun di Kota.

\section{Pengaruh Transparansi Kebijakan Publik Terhadap Pengawasan Keuangan Daerah}

Hasil pengujian menunjukkan bahwa variabel peran Transparansi kebijakan publik tidak berpengaruh dan signifikan secara statistik terhadap pengawasan keuangan daerah Diwilayah Sulawesi Utara. Dengan demikian hipotesis 2 terdukung karena secara empirik terbukti. Interpretasi dari temuan penelitian ini menunjukkan bahwa tidak terdapat hubungan antara peran transparansi kebijakan publik pada DPRD Provinsi dan Kota di wilayah Sulawesi Utara. Hal ini menunjukkan bahwa Transparansi kebijakan publik tidak berpengaruh terhadap pengawasan keuangan daerah. Artinya peran transparansi kebijakan publik tidak dapat berjalan sesuai dengan apa yang dilakukan terhadap pemerintah khususnya anggota dewan dikarenakan adanya keterbukaan anggaran untuk masyarakat sedangkan bagi pemerintah DPRD Provinsi dan Kota tidak dapat mengakses secara langsung tentang anggaran terhadap masyarakat.

Temuan ini sesuai dengan penelitian sebelumnya yang dilakukan oleh Sukoco (2016) dimana interaksi antara transparansi kebijakan publik terhadap pengawasan keuangan daerah tidak berpengaruh signifikan. Temuan ini tidak mendukung hasil penelitian sebelumnya yang dilakukan oleh Imam Ghozali (2015) mengenai Pengaruh partisipasi masyarakat dan transparansi kebijakan publik terhadap hubungan diantara pengetahuan dewan tentang anggaran dengan pengawasan keuangan daerah (APBD) Hasil hipotesisnya menunjukan bahwa Berdasarkan Hasil uji hipotesis ke empat dapat dilihat bahwa interaksi antara pengetahuan dewan tentang anggaran dengan partisipasi masyarakat dan transparansi kebijakan publik tidak berpengaruh positif signifikan terhadap pengawasan APBD.

Temuan ini sejalan dengan teori yang dikemukakan oleh pendapat Cleaves yang dikutip (dalam Wahab 2008:187), yang secara tegas menyebutkan bahwa Implementasi itu mencakup "Proses bergerak menuju tujuan kebijakan dengan cara langkah administratif dan politik". Keberhasilan atau kegagalan implementasi sebagai demikian dapat dievaluasi dari sudut kemampuannya secara nyata dalam meneruskan atau mengoperasionalkan program-program yang telah dirancang sebelumya. Hal ini mengkonfirmasi asumsi filosofis dari teori Peran dalam suatu lembaga berkaitan dengan tugas dan fungsi, yaitu merupakan seperangkat bidang pekerjaan yang harus dikerjakan dan melekat pada seseorang atau lembaga sesuai dengan fungsi yang dimilikinya.

\section{Pengaruh Akuntabilitas Publik Terhadap Pengawasan Keuangan Daerah}

Hasil pengujian menunjukkan bahwa variabel Akuntabilitas publik berpengaruh signifikan terhadap pengawasan keuangan daerah pada DPRD Provinsi dan Kota. Dengan demikian hipotesis 2 terdukung karena secara empirik terbukti. Interpretasi dari temuan penelitian ini menunjukkan bahwa terdapat hubungan antara akuntabilitas publik terhadap pengawasan keuangan daerah. Hal ini menunjukkan bahwa pengawasan keuangan daerah didukung oleh Akuntabilitas publik pada DPRD Provinsi dan Kota. Artinya pemerintah khususnya anggota dewan mampu meberikan informasi secara terbuka, cepat dan tepat kepada masyarakat. Dapat memberikan pelayanan yang memuaskan bagi publik.

Penelitian ini menunjukan bahwa peneliti Sukoco (2016) Pengaruh akuntabilitas publik, partisipasi masyarakat dan transparansi kebijakan publik terhadap hubungan antara pengetahuan anggaran dengan pengawasan keuangan daerah (APBD), Hasil penelitiannya menunjukan bahwa pertama, pengetahuan anggaran berpengaruh signifikan terhadap pengawasan (APBD) baik menurut sampel dewan maupun masyarakat. Pengaruh yang ditunjukan adalah positif artinya semakin tinggi pengetahuan dewan tentang anggaran maka pengawasan yang dilakukan semakin meningkat. Kedua, 
interaksi pengetahuan anggaran dan akuntabilitas publik berpengaruh signifikan terhadap pengawasn APBD baik menurut sampel dewan maupun sampel masyarakat. Hubungan yang ditunjukan adalah negatif artinya semakin tinggi akuntabilitas maka pengawasan yang dilakukan oleh dewan semakin menurun. Ketiga, interaksi pengetahuan anggaran dengan partisipasi masyarakat berpengaruh signifikan terhadap pengawasan APBD menurut dewan, sedangkan menurut masyarakat tidak signifikan. Keempat, interaksi pengetahuan anggaran dengan transparansi kebijakan publik tidak berpengaruh signifikan terhadap pengawasan APBD baik menurut dewan maupun masyarakat.

Temuan ini juga konsisten dengan penelitian yang dilakukan oleh Setiyawan (2016) yang berjudul Analisis Pengaruh Akuntabilitas Publik, Transparansi Publik dan Pengawasan Terhadap Kinerja Satuan Kerja Perangkat Daerah, Hasil penelitian yang menunjukkan pengaruh positif akuntabilitas publik, transparansi publik dan pengawasan terhadap pengelolaan keuangan daerah sesuai dengan prinsip pengelolaan keuangan daerah yang dikemukan oleh Halim (2012) dimana prisip-prinsip pengelolaan keuangan daerah: (1) akuntabilitas, (2) value for money, (3) kejujuran, (4) transparansi (5) pengendalian/pengawasan. Sama-sama meneliti tentang akuntabilitas publik, transparansi publik dan pengawasan. Persamaan Sama-sama meneliti tentang akuntabilitas publik, transparansi publik dan pengawasan. Perbedaan Membahas Analisa pengaruh akuntabilitas publik, transparansi publik, dan pengawasan terhadap kinerja satuan kerja perangkat daerah.

Temuan ini tidak mendukung hasil penelitian sebelumnya mengenai pengaruh pendidikan terhadap kualitas laporan keuangan seperti penelitian Wungow (2016). Hasil penelitiannya menunjukkan bahwa kualitas laporan keuangan pada Kabupaten Minahasa Selatan tidak dipengaruhi oleh tingkat pendidikan. Temuan ini sejalan dengan teori yang dikemukakan oleh Mardiasmo (2002:20) menyatakan bahwa Kewajiban pihak pemegang amanah untuk memberikan pertanggungjawaban, menyajikan, melaporkan dan mengungkapkan segala aktivitas kegiatan yang menjadi tanggungjawabnya kepada pihak pemberi amanah yang memiliki hak dan kewenangan untuk meminta pertanggungjawaban tersebut.

Hal ini mengkonfirmasi asumsi filosofis dari teori aksi yang menjelaskan bahwa seorang individu melakukan suatu tindakan berdasarkan atas pengalaman, persepsi, pemahaman, dan penafsirannya atas suatu obyek stimulus atau situasi tertentu. Dengan demikian dapat diartikan bahwa aksi merupakan kemampuan individu melakukan tindakan, dalam arti menetapkan pilihan atau cara atau alat dari sejumlah alternatif yang tersedia dalam rangka mencapai tujuan yang hendak dicapai. Pendidikan yang memadai mampu meningkatkan kinerja dengan baik seperti penata usahaan dan penyusunan laporan keuangan harus dilakukan dengan tindakan aksi yang konkrit.

\section{Penutup}

\section{Kesimpulan}

Berdasarkan hasil penelitian dan pembahasan maka dapat disimpulkan beberapa kesimpulan sebagai berikut:

1. Pengetahuan tentang anggaran $\left(X_{1}\right)$ berpengaruh positif dan siginifikan terhadap pengawasan keuangan daerah (Y). Hal ini menunjukkan bahwa semakin tinggi pengetahuan tentang anggaran seluruh anggota dewan maka semakin tinggi pula pengawasan keuangan daerah yang dihasilkan.

2. Partisipasi masyarakat $\left(\mathrm{X}_{2}\right)$ berpengaruh positif dan signifikan terhadap pengawasan keuangan daerah (Y). Hal ini menunjukkan bahwa semakin tinggi partsipasi masyarakat maka semakin tinggi pengawasan keuangan daerah yang dihasilkan.

3. Transparansi kebijakan publik $\left(\mathrm{X}_{3}\right)$ tidak berpengaruh signifikan terhadap pengawasan keuangan daerah (Y). Hal ini menunjukkan bahwa tinggi rendahnya Transparansi Kebijakan Publik (X3) tidak mempengaruhi terhadap Pengawasan Keuangan Daerah (Y).

4. Akuntabilitas publik $\left(\mathrm{X}_{4}\right)$ berpengaruh positif dan siginifikan terhadap pengawasan keuangan daerah (Y). Hal ini menunjukkan bahwa semakin tinggi partsipasi masyarakat maka semakin tinggi pengawasan keuangan daerah yang dihasilkan.

5. Variabel pengetahuan tentang anggaran $\left(X_{1}\right)$, partisipasi masyarakat $\left(X_{2}\right)$, transparansi kebijakan publik $\left(\mathrm{X}_{3}\right)$, dan akuntabilitas publik $\left(\mathrm{X}_{4}\right)$ secara simultan berpengaruh terhadap pengawasan keuangan daerah. 


\section{Saran}

Berdasarkan hasil penelitian dan pembahasan, maka dapat dikemukakan beberapa saran sebagaimana berikut ini:

1. Saran bagi pemerintah daerah Provinsi Sulawesi Utara :

a) Pengetahuan tentang anggaran penting dalam meningkatkan pengawasan keuangan daerah, oleh karena itu seluruh anggota dewan harus lebih memahami dan mengetahui lebih baik lagi dalam hal pengawasan keuangan daerah.

b) Partisipasi masyarakat sangat penting dalam masyarakat memberikan aspirasinya kepada pemerintah khususnya anggota dewan agar dapat mengambil suatu keputusan ketika nantinya mereka melakukan rapat pembahasan tentang penyusunan APBD terhadap pengawasan keuangan daerah.

c) Transparansi kebijakan publik juga sangat penting agar masyarakat mudah mengakses dokumen tentang anggaran.

d) Akuntabilitas publik sangat penting dalam meningkatkan pengawasan keuangan daerah, agar masyarakat (publik) bisa dilibatkan langsung dalam suatu perancangan terhadap kebijakan dalam perencanaan suatu pembangunan dan juga semua proses dan prosedur tentang anggaran dapat mensejahterakan masyarakat, dan bisa mengakses dokumen secara terbuka.

2. Saran bagi peneliti selanjutnya, agar memperdalam hasil temuan penelitian ini dengan menambah variabel-variabel yang berperan penting terhadap pengawasan keuangan daerah dan kemudian diharapkan kepada peneliti selanjutnya harus mencari lebih dalam lagi tentang apa yang mempengaruhi transparansi kebijakan publik terhadap pengawasan keuangan daerah kenapa bisa terjadi ketidaksignifikan.

\section{Daftar Pustaka}

Amin, Widjaja Tunggal. 2008. Dasar-dasar Customer Relationship Management (CRM). Jakarta: Harvindo.

Budiardjo, Miriam. 2008. Dasar-dasar Ilmu Politik. Jakarta: PT. Gramedia Pustaka Utama.

Corynata, Isma. 2007. Akuntabilitas, Partisipasi Masyarakat, dan Transparansi Kebijakan Publik Sebagai Pemoderating hubungan Pengetahuan Dewan tentang Anggaran dan Pengawasan Keuangan Daerah (APBD). Simposium Nasional Akuntansi X Universitas Hassanudin.

Devi, Nirmala. 2010. Sektor Publik Pemerintah. Media Akuntansi. Edisi 26. BPK RI Laporan Hasil Pemeriksaan BPK RI Atas Laporan Keuangan Pemerintah.

Ghozali, Imam. 2015. Pengaruh Partisipasi Masyarakat Dan Transparansi Kebijakan Publik Terhadap Hubungan Antara Pengetahuan Dewan Tentang Anggaran Dengan Pengawasan Keuangan Daerah. Tesis Studi Empiris Yogyakarta.

Ghozali, Imam. 2016. Akuntansi Keuangan, Badan Penerbit Universitas Diponegoro, Semarang.

Halim, Abdul. 2004. Bunga Rampai Manajemen Keuangan Daerah. Edisi Revisi Kesatu. Jogjakarta: Penerbit UPP AMP YKPN.

Mardiasmo. 2002. Otonomi dan Manajemen Keuangan Daerah. Yogyakarta: ANDI

Nasirwan. 2008. Pengaruh Pengetahuan Anggota Dewan Tentang Anggaran Terhadap Pengawasan Keuangan Daerah Dengan Partisipasi Masyarakat, Transparansi Kebijakan Publik Dan Pendidikan/Pelatihan Sebagai Variabel Moderating. http://isjd.pdii.lipi.go.id/admin/jurnal/Ed19Jan09121.pdf

Novatianti, R., Ait dan Nurmalita Lestari. 2010. Pengaruh Akuntabilitas Publik, Partisipasi Masyarakat dan Transparansi Kebijakan Publik Terhadap Pengawasan Keuangan Daerah. Bandung. 
Pangesti, Isa. 2013. Analisis pengetahuan dewan tentang pengawasan keuangan daerah (APBD) dengan menggunakan variabel moderating. Accounting Analysis Journal AAJ 1(3) 2013.

Peraturan Pemerintah Nomor 105 Tahun 2000 Tentang Pengelolaan Dan Pertanggungjawaban Keuangan Daerah.

Pramono, Agus H. 2002. Pengawasan Legislatif Terhadap Eksekutif Dalam Penyelenggaraan Pemerintah Daerah. Tesis S2 Di Publikasikan, Program Pasca Sarjana Ilmu Administrasi Negara, Universitas Brawijaya, Malang.

Putro, Andik Cahyo. 2013. Aplikasi Pengelolaan Publikasi Mahasiswa Fakultas Komunikasi dan Informatika, Universitas Muhammadiyah, Surakarta.

Ritzer, George. 1992. Sosiologi Ilmu Pengetahuan Berparadigma Ganda, Teori Aksi (Grand Teori) Jakarta: PT. Raja Grafindo Persada.

Roseptalia, Rima. 2006. Pengaruh Pengetahuan Dewan tentang Anggaran terhadap Pengawasan Keuangan Daerah dengan Variabel Moderator Partisipasi Masyarakat dan Transparansi Kebijakan Publik. Tesis UII: Yogyakarta.

Rubin, Irene. 1996. Budgeting for Accountability: Municipal Budgeting for the 1990s. Jurnal Public Budgeting \& Finance, Summer, hal. 112-132.

Rustiyaningsih, Sri. 2013. Pengaruh Pengetahuan Dewan Tentang Anggaran Terhadap Pengawasan Keuangan Daerah (APBD) Dengan Variabel Moderating Partisipasi Masyarakat Dan Transparansi Kebijakan Publik. Tesis Studi Empiris Kalimantan Barat.

Saputro. 2012. Pemanfaatan Hasil Mengelola Pelatihan Partisipasi. Bandung: Disampaikan dalam Lokakarya Pemberdayaan Masyarakat dalam Pendidikan Luar Sekolah. BAPPEDA Bantu. Yogyakarta.

Saputro, Aditya Dibyo. 2013. Pengaruh Partisipasi Masyarakat Dan Transparansi Kebijakan Publik Terhadap Hubungan Pengetahuan Dewan Tentang Anggaran Dengan Pengawasan Keuangan Daerah (Studi Empiris Di DPRD Kabupaten Boyolali). Tesis Universitas Muhammadiyah Surakarta

Setiyawan, Hari Eka. 2016. Analisis Pengaruh Akuntabilitas Publik, Transparansi Publik dan Pengawasan Terhadap Kinerja Satuan Kerja Perangkat Daerah. Tesis Studi Empiris Di Kabupaten Bungo

Sopanah. 2003. Pengaruh Partisipasi Masyarakat dan Transparansi Kebijakan Publik Terhadap Hubungan antara Pengetahuan Dewan tentang Anggaran dengan Pengawasan Keuangan Daerah, dalam Proceding Simposium Nasional akuntansi VI, Membangun Citra Akuntan melalui Peningkatan Kualitas Pengetahuan, Pendidikan dan Etika Bisnis, Surabaya, 16-17

Sopanah dan Wahyudi. 2009. Pengaruh Akuntabilitas Publik, Partisipasi Masyarakat Dan Transparansi Kebijakan Publik Terhadap Hubungan Antara Pengetahuan Anggaran Dengan Pengawasan Keuangan Daerah (APBD). Tesis Studi Empiris Universitas Widya Gama Malang. http://journal.usu.ac.ad/bitstream/123456789/29358/2/reference.p df

Sudiarta, I Dewa Gede. 2014. Analisis Pengaruh Pengetahuan Dewan Tentang Anggaran Terhadap Pengawasan Keuangan Daerah Dengan Akuntabilitas Publik, Partisipasi Masyarakat Dan Transparansi Kebijakan Publik Sebagai Variabel Pemoderating. Ganesha Singaraja, Indonesia. 
Sukoco, Manik. 2016. Pengaruh Akuntabilitas Publik, Partisipasi Masyarakat dan Transparansi Kebijakan Publik Terhadap Hubungan Antara Pengetahuan Anggaran dengan Pengawasan Keuangan Daerah. Tesis Studi Empiris Kota Malang.

Sulistoni, G. 2003. Etika Dalam Wujud Akuntabilitas Penyelenggaraan Pemerintah. https://jurnal.unigal.ac.id/index.php/dinamika/article/view/877.

Syaiful. 2009. Manajemen Strategi dalam Peningkatan Mutu Pendidikan dan akuntansi. Bandung: Alfabeta.

Undang-Undang Nomor 23 Tahun 2014 Tentang Pemerintah Daerah.

Utama, Maulana Hardia. 2015. Pengaruh Pengetahuan Dewan Tentang Anggaran Terhadap Pengawasan Keuangan Daerah Dengan Partisipasi Masyarakat Dan Transparansi Kebijakan Publik Sebagai Variabel Moderating. Jurnal Akuntansi.

Yudono, Bambang. 2002. Optimalisasi Peran DPRD dalam Penyelenggaraan Pemerintah Daerah.

Wahab, Abdul Solichin. 2008. Analisis Kebijakan Dari Formulasi Ke Implementasi Kebijaksanaan Negara. Jakarta: Bumi Aksara.

Werimon, Simson. 2005. Pengaruh Partisipasi Masyarakat dan Transparansi Kebijakan Publik terhadap Hubungan antara Pengetahuan Dewan Tentang Anggaran dengan Pengawasan Keuangan Daerah (APBD) Studi empiris di Provinsi Papua. Universitas Diponegoro, Semarang.

Werimon, Simson, Ghozali, Imam, dan Nazir, Mohamad. 2007. Pengaruh Partisipasi Masyarakat dan Transparansi Kebijakan Publik terhadap Hubungan antara Pengetahuan Dewan Tentang Anggaran dengan Pengawasan Keuangan Daerah (APBD) Studi empiris di Provinsi Papua. Tesis Studi Empiris di kota Semarang.

Wungow, J., F. 2016. Pengaruh Tingkat, Masa Kerja, Pelatihan dan Jabatan Terhadap Kualitas Laporan Keuangan Pemerintah Kabupaten Minahasa Selatan. Jurnal Riset Akuntansi dan Auditing Goodwill, 7(2), hal 174-188. 